\title{
Preferencje aksjologiczne dzieci i młodzieży z pogranicza polsko-czeskiego. Od wartości materialnych do postmaterialnych
}

Streszczenie: W opracowaniu scharakteryzowano przemiany w zakresie wartości cenionych przez dzieci i młodzież z pogranicza polsko-czeskiego - odwołując się do sformułowanych przez R. F. Ingleharta hipotez niedoboru i socjalizacji. Zakładają one - po pierwsze - że priorytetowe wartości jednostki odzwierciedlają jej środowisko społeczno-ekonomiczne, a przedmiotom, których jest w nim stosunkowo niewiele, nadaje się subiektywnie wyższą wartość i - po drugie - podstawowa struktura wartości jednostki odzwierciedla warunki, w jakich została ona wychowana.

Przeprowadzenie badań w latach 1990-1991 oraz 2014-2015 - z wykorzystaniem strategii porównań podłużnych, opartej na kryterium czasu - umożliwiło poznanie czynników oddziałujących na preferencje aksjologiczne młodego pokolenia, jak również przedstawienie względnej dynamiki zmiany i uchwycenie wyznaczających ją mechanizmów.

Słowa kluczowe: wartości, preferencje aksjologiczne, pogranicze kulturowe, edukacja wielo- i międzykulturowa

\section{Wprowadzenie}

Proces transformacji ustrojowej, który rozpoczął się zarówno w Polsce, jak i w Republice Czeskiej w 1989 roku, spowodował szereg gruntownych zmian w sferze społeczno-kulturowej, w systemach wartości jednostek oraz zmienił wzory zachowań. Po dość burzliwym okresie przechodzenia od realnego socjalizmu do realnej demokracji, współczesne dzieci i młodzież stają się kontynuatorem społecznych przemian, biorąc w nich udział i po części je kształtując. To, w jaki sposób młodzi ludzie postrzegają dane państwo/państwa i społeczeństwo/społeczeństwa oraz zachodzące w nich zmiany, jakimi kryteriami kierują się w dokonywaniu ocen, jak chcieliby budować życie własne i społeczne, co uznają za godne naśladowania, a co stanowczo odrzucają 
- jest w znacznej mierze wynikiem oddziaływania różnych kierunków i trendów myślowych, ścierających się ze sobą w środowiskach, w których młodzi egzystują i uczą się.

Przy całej złożoności współczesnych procesów społecznych i kulturowych pojawiają się istotne - szczególnie z punktu widzenia edukacji młodego pokolenia - pytania: Jak z upływem czasu, ponad dwie dekady po dokonanym przełomie politycznym i społeczno-kulturowym, przedstawia się obraz preferencji aksjologicznych dzieci i młodzieży? Czy są oni bardziej świadomi i wrażliwi na wartości, czy też sceptyczni - bez orientacji i perspektyw życiowych na przyszłość w swoim kraju zamieszkania? Czy przyjęcie przez młodego człowieka gotowej tożsamości jest efektem masowej kultury, czy raczej spadku zaufania do starszego pokolenia, związanego z brakiem autorytetów moralnych i politycznych? Czy - podobnie jak to miało miejsce w krajach zachodnich - w przypadku polskiego młodego pokolenia żyjącego w naszym kraju i Republice Czeskiej możemy mówić, odwołując się do teorii sformułowanej przez R. F. Ingleharta, o zachodzeniu „cichej rewolucji” wartości, polegającej na przechodzeniu od preferencji wartości materialnych po rozwój wartości postmaterialnych i będącej pozytywną zmianą, zgodną z transformacją społeczeństwa industrialnego w społeczeństwo usług? Czy i w jakim zakresie potwierdzają się w środowiskach zróżnicowanych kulturowo sformułowane przez Ingleharta hipotezy niedoboru i socjalizacji, zakładające po pierwsze - iż priorytetowe wartości jednostki odzwierciedlają jej środowisko społeczno-ekonomiczne, a przedmiotom, których jest w nim stosunkowo niewiele, nadaje się subiektywnie wyższą wartość, i po drugie podstawowa struktura wartości jednostki odzwierciedla warunki, w jakich została ona wychowana ${ }^{1}$ ?

Podjęcie próby odpowiedzi na powyższe pytania może w znacznym zakresie przyczynić się do lepszej orientacji w stanie świadomości dzieci i młodzie-

1 R. F. Inglehart et al.: World values surveys an European values surveys, 1999-2001. User guide and codebook. Michigan 2004, University of Michigan. Tenże: Pojawienie się postmaterialnych wartości. W: P. Sztompka, M. Kucia (red.): Socjologia. Lektury. Kraków 2007, „Znak”. R. F. Inglehart ulokował wartości w dwóch wymiarach - (1) na wymiarze rodzaju uznawanego autorytetu: tradycyjnego (głównie religijnego) vs świecko-racjonalnego oraz (2) na wymiarze wartości materialistycznych (przeżycie) vs posmaterialistycznych (jakość życia). Za: M. Lewicka: „Polacy sq wielkim i dumnym narodem", czyli nasz portret (wielce) zróżnicowany. W: M. Drogosz (red.): Jak Polacy przegrywaja, Jak Polacy wygrywają. Gdańsk 2005, GWP, s. 17; P. Zdziech: Ronalda Ingleharta teoria rozwoju ludzkiego. Kraków 2010, Zakład Wydawniczy „Nomos”. 
ży z pogranicza polsko-czeskiego i zrozumienia ich świata wartości, celów oraz dążeń życiowych, i tym samym wzbogacić dotychczasowe doświadczenia edukacji międzykulturowej w tym zakresie.

Wyniki badań prezentowane w tym opracowaniu, przeprowadzonych na przełomie 2014 i 2015 roku, to zapis stanu współczesnego, po ponad 24 latach przemian społeczno-cywilizacyjnych, które swym oddziaływaniem objęły zarówno społeczności Polaków, jak i Czechów (wejście do NATO w 1999 roku, do Unii Europejskiej w roku 2004, do strefy Schengen w 2007 roku) ${ }^{2}$.

W najnowszych badaniach posłużono się strategią porównań podłużnych, opartą na kryterium czasu i służącą zrozumieniu mechanizmów zmian oraz czynników oddziałujących na zachowanie grup i poszczególnych jednostek żyjących w tym samym okresie społeczno-ekonomicznym i kulturowym. Zastosowano badania sondażowe z wykorzystaniem metody panelowej (powtarzalnej), zakładającej przeprowadzenie przynajmniej dwukrotnie, w pewnym odstępie czasu, pomiaru pewnej liczby osób ze względu na tę samą cechę. Ich celem jest uchwycenie dynamiki jakiegoś zjawiska. Pozwalają one nie tylko przedstawić względną dynamikę zmiany, ale także uchwycić pewne mechanizmy ją wyznaczające ${ }^{3}$.

Model analizy badanych zagadnień ujęto operacyjnie w postaci wielozmiennowej analizy wariancji z pomiarami zmiennych - podobnie jak w badaniach przeprowadzonych na przełomie lat 1990/1991 - w dwóch środowiskach: Polaków mieszkających i uczących się w Polsce oraz dzieci i młodzieży narodowości polskiej mieszkającej na Zaolziu w Republice Czeskiej i uczącej

2 Badania zarówno w roku 1990-1991, jak i w roku 2014-2015 przeprowadzili pracownicy Zakładu Pedagogiki Ogólnej (aktualnie Zakładu Pedagogiki Ogólnej i Metodologii Badań) Uniwersytetu Śląskiego, Wydziału Etnologii i Nauk o Edukacji w Cieszynie, pod kierunkiem naukowym prof. zw. dra hab. T. Lewowickiego. Założenia teoretyczno-metodologiczne badań, ich rezultaty i interpretacje są szerzej nakreślone w książce autorstwa T. Lewowickiego, E. Ogrodzkiej-Mazur, A Minczanowskiej i G. Piechaczek-Ogierman: Sfery życia duchowego dzieci i młodzieży - studium z pogranicza polsko-czeskiego. T. 1. Przemiany wartości i aspiracji życiowych. Cieszyn - Toruń 2016, Wydział Etnologii i Nauk o Edukacji Uniwersytetu Śląskiego, Wydawnictwo Adam Marszałek (w druku).

3 Por.: Ch. Frankfort-Nachmias, D. Nachmias: Metody badawcze w naukach spotecznych. Poznań 2001, Zysk i S-ka, s. 153-154; E. Hajduk (red.): Metoda panelu: różne aplikacje. Zielona Góra 1993, WSP; T. Pilch, T. Bauman: Zasady badań pedagogicznych. Podejście ilościowe i jakościowe. Warszawa 2001, Wydawnictwo Akademickie „Żak”, s. 39-42. 
się w tamtejszych szkołach z polskim językiem nauczania. Model ten umożliwił zweryfikowanie hipotezy o podobieństwach i różnicach występujących między badanymi grupami dzieci i młodzieży w zakresie cenionych wartości.

Badaniami objęto łącznie 377 uczniów, w tym 183 dzieci oraz młodzież z polskich publicznych i niepublicznych szkół podstawowych i gimnazjalnych (105 dziewcząt i 78 chłopców) funkcjonujących w Cieszynie i ich 194 rówieśników z Republiki Czeskiej (87 dziewcząt i 107 chłopców), uczących się w szkołach podstawowych z polskim językiem nauczania na terenie powiatu karwińskiego i frydecko-misteckiego.

Podobnie, jak w badaniach przeprowadzonych w roku 1990/1991, aktualnie uczestniczyli w nich zarówno uczniowie z klas IV, szkół podstawowych (61 dzieci z Polski i 74 z Zaolzia), jak również młodzież z II klas gimnazjalnych z Polski (122 osoby) i uczniowie z VIII klas ze szkół podstawowych z Zaolzia (120 osób). W czeskim systemie oświaty klasa VIII szkoły podstawowej jest odpowiednikiem II klasy polskiego trzyletniego gimnazjum.

Badana społeczność uczniów z pogranicza polsko-czeskiego zarówno na początku lat 90. ubiegłego wieku, jak i współcześnie obserwowała i nadal obserwuje przemiany zachodzące w Polsce i Republice Czeskiej. Są to zmiany częściowo podobne, ale również zachowujące odrębne właściwości. Dzieci i młodzież z zaolziańskich szkół z polskim językiem nauczania, będące obywatelami Republiki Czeskiej i przejawiające najczęściej poczucie polskiej narodowości, zjawiska te postrzegają jeszcze z innej perspektywy, żyjąc na co dzień w środowiskach, a także często w rodzinach zróżnicowanych kulturowo. Ma to zasadnicze znaczenie w kształtowaniu (się) ich wielowymiarowej tożsamości kulturowej oraz indywidualnej struktury rzeczywistości aksjologicznej.

\section{Obraz wartości cenionych przez dzieci}

W aktualnej strukturze wartości preferowanych przez dzieci z klas IV z Zaolzia można wyodrębnić dominujący zespół wartości życia rodzinnego (80\%), wygodnego (65\%) oraz atrakcyjnego (58\%). Wartości rodzinne nadal zajmują wysoką pozycję w wyborach dokonywanych przez uczniów, które wskazują na zachowywaną swoistą ciągłość pokoleniową - rodzina jest najwyżej cenioną wartością, podstawowym środowiskiem wychowawczym oraz miejscem przekazu wartości (por. wykres 1). 
Wykres 1. Wartości preferowane przez uczniów z klas IV z Polski i Republiki Czeskiej

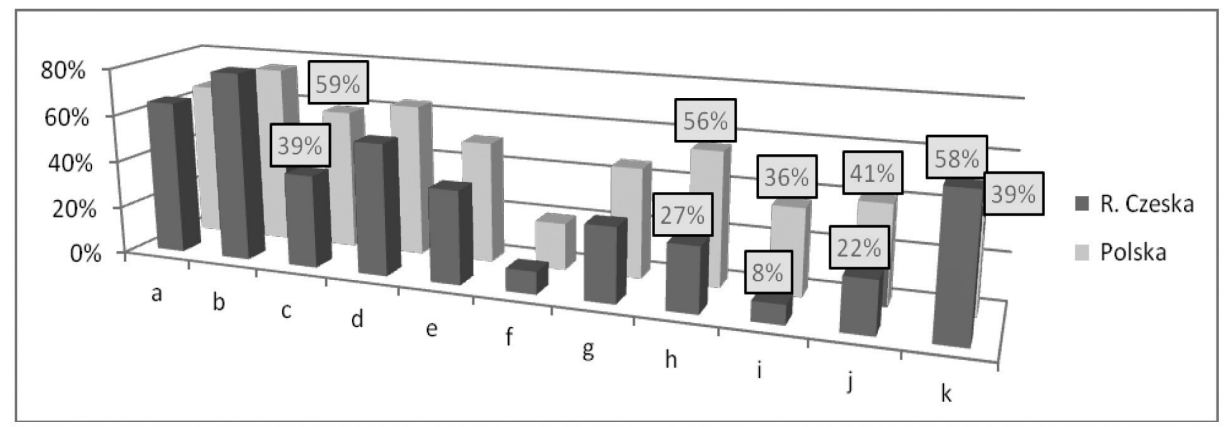

Legenda: a. wygodne życie, wolne od problemów; b. spokojne życie w gronie rodziny i przyjaciół; c. popularność, sława, sukcesy; d. pasjonująca praca, kariera zawodowa; e. wiedza, wykształcenie, osiągnięcia naukowe; f. wysokie stanowisko, kierowanie ludźmi, podejmowanie decyzji; g. duży majątek, wysoki standard życia; h. realizacja wartości moralnych, życie wzbudzające szacunek; i. zaangażowanie w sprawy społeczne, aktywność obywatelska; j. udział w kulturze, aktywność artystyczna, twórczość; k. życie pełne zmian, przygód, atrakcji

Źródło: badania własne.

Wartość człowieka i rodziny w rodzinach na Śląsku Cieszyńskim budowana była, jeszcze do niedawna, w świadomości jej członków, od dzieciństwa. Na straży przekazu wiedzy o tych wartościach stały, wpajane kolejnym pokoleniom, normy zachowań związane ze sposobem i stylem życia codziennego, jakie wyznaczały poczucie odpowiedzialności za rodzinę, odpowiedzialności wobec Boga i społeczności. Wynikały one z wiary i religijności, z warunków życia i pracy. W codziennym życiu preferowano wzory postępowania oparte na Dekalogu i życiowym doświadczeniu ludzi starszych. Na ukształtowanie się specyfiki systemu wartości tych rodzin oddziaływały zatem nie tylko ich wewnętrzna organizacja, lecz także tworzona i użytkowana przez pokolenia kulturowa przestrzeń środowiska i domu rodzinnego, praca, życie religijne i kulturalne oraz kształtowane poczucie tożsamości regionalnej i narodowej

4 Por. m.in. artykuły: E. Ogrodzkiej-Mazur: Rodzina jako środowisko rozwijania kompetencji aksjologicznych dziecka $w$ warunkach wielokulturowego Pogranicza; A. Różańskiej: Zaolziańskie rodziny mieszane wyznaniowo a wychowanie międzykulturowe; A. Szczypki-Rusz: Wspótczesna rodzina cieszyńska. Kim sa rodzice? Kim chcieliby, żeby byty ich dzieci - rzecz o tożsamości i A. Szczurek-Boruty: Oddziatywania socjalizacyjno-wychowawcze $w$ rodzinie $w$ zróżnicowanym środowisku Pogranicza zawarte w tomie: T. Lewowicki, J. Suchodolska (red.): Rodzina - Wychowanie - Wie- 
Współczesne młode pokolenie nadal najwyżej ceni udane życie rodzinne, pełne miłości i wzajemnego szacunku, ale także deklaruje potrzebę życia wygodnego, wolnego od problemów i - co typowe dla tego wieku rozwojowego - pełnego zmian, przygód i atrakcji.

Mniejszą wagę przywiązują czwartoklasiści ze szkół z polskim językiem nauczania do wartości związanych z pracą i karierą zawodową (55\%), popularnością i odnoszeniem sukcesów (39\%) oraz wiedzą i wykształceniem (39\%). Swoista deprecjacja wartości nauki, wiedzy i wykształcenia przez aktualne młode pokolenie może świadczyć o ich realnej ocenie możliwości realizacji tych wartości w przyszłości lub o braku - ze względu na wiek - jeszcze tego typu refleksji. Może na to również wskazywać jeszcze niższa ranga i znaczenie, jakie przypisują badani wartościom materialnym (31\%) oraz realizacji wartości moralnych i życiu wzbudzającego szacunek (27\%).

W najmniejszym zakresie uczniowie zaolziańscy cenią i zamierzają podejmować aktywność kulturalną i artystyczną (22\%), zajmować wysokie stanowiska związane z kierowaniem innymi ludźmi (9\%) oraz angażować się w sprawy społeczne (8\%).

Odmienny obraz preferencji aksjologicznych i celów życiowych charakteryzuje dzieci z klas IV z Polski. Uczniowie cenią zdecydowanie wyżej wszystkie wybierane wartości, które tworzą określone trzy podstruktury (por. wykresy 1 i 2). W pierwszym, wyraźnie dominującym podsystemie, lokują się wartości życia w gronie rodziny (75\%), życia wolnego od problemów (66\%), kariery zawodowej związanej z wykonywaniem w przyszłości pasjonującej pracy (64\%) oraz sławy, sukcesu i popularności (59\%). W drugim, niżej preferowanym podsystemie znalazły się wybory dotyczące życia wzbudzającego szacunek, zgodnego z przyjętymi normami etycznymi (56\%), wartości wiedzy i wykształcenia (51\%) oraz osiągnięcia wysokiego standardu życia, w tym dużego majątku (46\%).

Dzieci z Polski najmniej cenią i przywiązują wagę do uczestnictwa w kulturze (41\%), życia pełnego zmian przygód i atrakcji (39\%), aktywności

lokulturowość. Cieszyn 2000, UŚ - Filia w Cieszynie, Wyższa Szkoła Pedagogiczna ZNP w Warszawie oraz rezultaty badań autorki artykułu zamieszone w opracowaniu: Rodzina i dziecko w otoczeniu wielokulturowym. Relacje międzypokoleniowe i ich rola w przekazie wartości. W: T. Lewowicki, E. Ogrodzka-Mazur, A. Szczurek-Boruta (red.): Edukacja międzykulturowa - dokonania, problemy, perspektywy. Cieszyn - Warszawa - Toruń 2011, Wydział Etnologii i Nauk o Edukacji Uniwersytetu Śląskiego, Wyższa Szkoła Pedagogiczna ZNP w Warszawie, Wydawnictwo Adam Marszałek, s. 15-71. 
obywatelskiej (36\%) oraz zajmowania w przyszłości wysokich stanowisk i kierowania innymi ludźmi (20\%).

Wykres 2. Porównanie wartości preferowanych przez uczniów z klas IV z Polski i Republiki Czeskiej

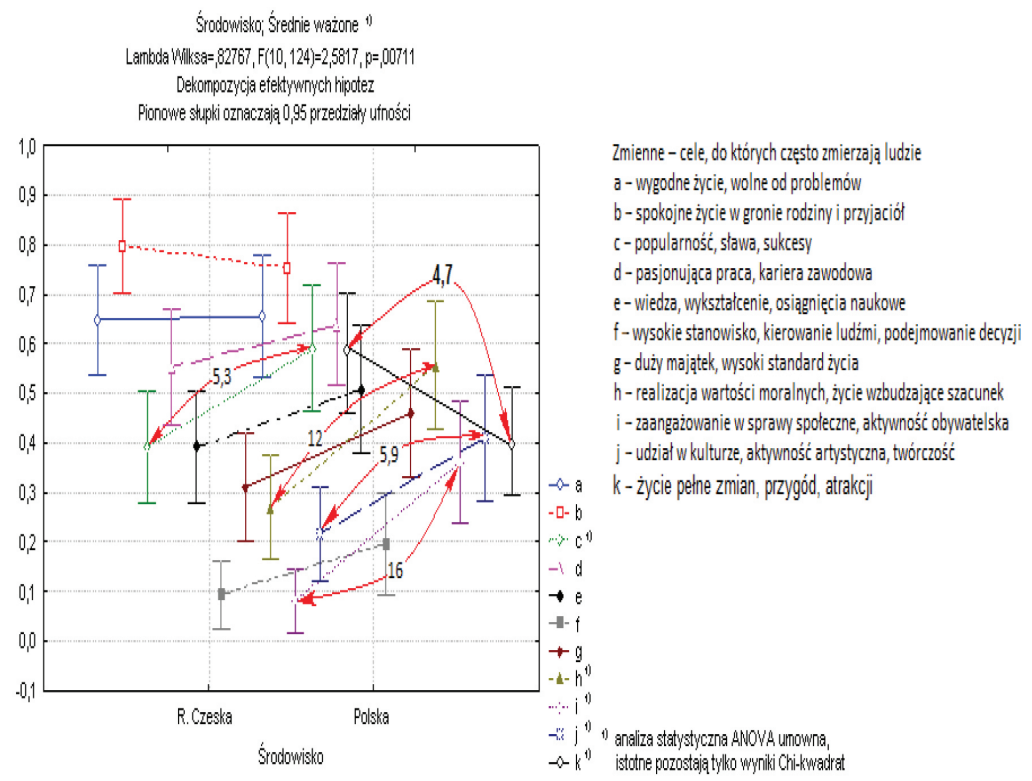

Źródło: badania własne.

Uzyskane rezultaty badań wskazują na różnice w deklarowanych przez czwartoklasistów z Zaolzia i polskiej części pogranicza wyborach wartości. Dzieci z Polski preferują częściej niż ich rówieśnicy z Zaolzia jako ważne cele w ich życiu:

- dążenie do popularności, sławy i sukcesu $\left(\mathrm{X}^{2}=5,3 ; \mathrm{p}<0,05\right.$; dla df $=$ $1)^{5}$,

- realizację wartości moralnych i życie wzbudzające szacunek $\left(\chi^{2}=11,5\right.$; $\mathrm{p}<0,05$; dla df $=1$ ),

- zaangażowanie w sprawy społeczne i aktywność obywatelską $\left(\chi^{2}=15,9\right.$; $\mathrm{p}<0,05$; dla df $=1$ ),

- udział w kulturze, aktywność artystyczną i twórczość ( $\chi^{2}=5,9 ; \mathrm{p}<0,05$; dla $\mathrm{df}=1)$.

5 Wszystkie różnice między wynikami, przy których p < 0,05, są statystycznie istotne. 
Z kolei uczniowie z IV klas ze szkół z polskim językiem nauczania deklarują życie pełne zmian, przygód i atrakcji jako cel w życiu częściej niż ich rówieśnicy z Polski $\left(\mathrm{X}^{2}=4,7 ; \mathrm{p}<0,05\right.$; $\left.\mathrm{dla} \mathrm{df}=1\right)$.

Tak zróżnicowany obraz aktualnie cenionych wartości przez najmłodsze, uczące się pokolenie wskazuje na zmiany zachodzące w ich świadomości aksjologicznej, warunkowane szczególną dla tego wieku wrażliwością społeczną i zarazem odczuwaną odmiennością kondycji ekonomicznej, gospodarczej i kulturowej każdego z krajów ich zamieszkania. Wartości i cele życiowe uczniów wydają się podobne do typowych cech obrazu wartości cenionych przez współczesną młodzież z wyraźną tendencją do ześrodkowania uwagi na życiu dla siebie, wzrostem znaczenia wartości indywidualno-prywatnych, związanych z pracą, karierą zawodową, samorealizacją i odniesieniem w życiu sukcesu.

Uzyskane wyniki badań są również zbliżone do stworzonego - na podstawie badań przeprowadzonych w siedmiu krajach europejskich (Wielka Brytania, Niemcy, Włochy, Holandia, Polska, Grecja, Szwecja) - zbioru wartości cenionych przez młodych ludzi, obejmujących: tradycję (uznawanie znaczenia rodziny i autorytetu rodziców), indywidualność (poczucie autonomii i niezależności), uczciwość (wyrażaną postawą przyjaźni i lojalności wobec innych), wysitek (przypisywanie znaczenia etyce pracy i nastawienie na sukces) oraz optymizm (pozytywne myślenie jako klucz do sukcesu i szczęśliwego życia $)^{6}$. Preferencje aksjologiczne dzieci z Polski wskazują tym samym na ich wyraźną życiową „akcelerację”, warunkowaną w dużym zakresie postawami rodziców i wzorami lansowanymi przez kulturę masową.

Charakteryzując przemiany w zakresie wartości i celów życiowych deklarowanych przez czwartoklasistów z Zaolzia, warto odnieść się do wyników badań przeprowadzonych na pograniczu polsko-czeskim na początku lat 90. ubiegłego wieku (por. wykres 3) ${ }^{7}$. Preferowane aktualnie wartości przez uczniów i ich struktura nieznacznie różnią się od wyborów dokonanych 25 lat temu przez ich rówieśników uczęszczających do szkół z polskim językiem nauczania. Współcześni uczniowie większe znaczenie przypisują jedynie pracy i karierze zawodowej, natomiast jeszcze mniej cenią zajmowanie wysokich stanowisk i kierowanie ludźmi oraz angażowanie się w sprawy społeczne i aktywność obywatelską. Tak zbliżona struktura wartości i funkcjonu-

6 M. Kleszcz, M. Łączyk: Młodzież licealna wobec wartości, samotności i pasji. Katowice - Kraków 2012, UŚ, Oficyna Wydawnicza „Impuls” s. 33-34.

E. Ogrodzka-Mazur: Systemy wartości, aspiracje i plany życiowe uczniów klas czwartych z Czeskiego Cieszyna i Orłowej. W: T. Lewowicki (red.): Hierarchia wartości i plany życiowe dzieci z Zaolzia. Cieszyn 1992, UŚ - Filia w Cieszynie, s. 9-23. 
jące w jej obrębie podsystemy - mimo upływu ponad dwóch dekad - mogą po pierwsze - potwierdzać małą podatność na zmiany społeczności polskiej mieszkającej na Zaolziu, determinowaną bardziej tradycyjnym, rodzinnym wychowaniem, przywiązaniem do przeszłości i zachowywaną swoistą ciągłością pokoleniową. W rodzinie zaolziańskiej w dalszym ciągu mamy do czynienia z poszanowaniem dla rodziców i osób starszych, poczuciem silnej więzi emocjonalnej i towarzyskiej z bliższymi i dalszymi krewnymi, przekazywaniem tradycji i zwyczajów, norm moralnych i obyczajowych.

Wykres 3. Wartości preferowane przez uczniów z klas IV z Polski i Republiki Czeskiej w roku 1990 i 2015

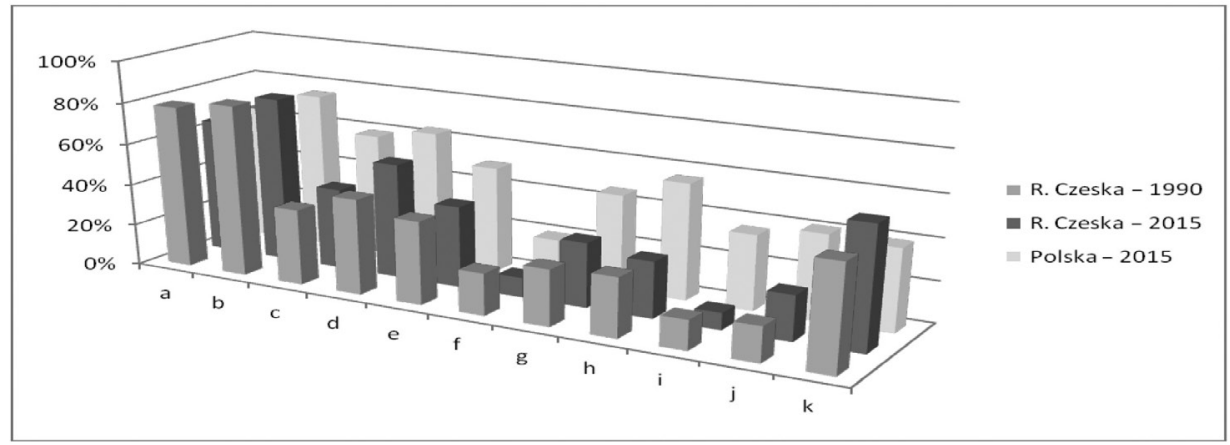

Legenda: a. wygodne życie, wolne od problemów; b. spokojne życie w gronie rodziny i przyjaciół; c. popularność, sława, sukcesy; d. pasjonująca praca, kariera zawodowa; e. wiedza, wykształcenie, osiągnięcia naukowe; f. wysokie stanowisko, kierowanie ludźmi, podejmowanie decyzji; g. duży majątek, wysoki standard życia; h. realizacja wartości moralnych, życie wzbudzające szacunek; i. zaangażowanie w sprawy społeczne, aktywność obywatelska; j. udział w kulturze, aktywność artystyczna, twórczość; k. życie pełne zmian, przygód, atrakcji

Źródło: badania własne.

Strategie kulturalizacyjne wybierane przez dzieci z Czeskiego Cieszyna wskazują na dominację profilu etnicznego (43\%) nad integracyjnym (38\%) oraz rozproszonym (14\%) i narodowym (5\%), co oznacza, że w zakresie tożsamości, języka i kontaktów społecznych bliższy jest uczniom wymiar regionalny (śląski, zaolziański) niż polski czy czeski, przy czym dzieci z Czeskiego Cieszyna deklarują chęć uczestniczenia w kulturze czeskiej częściej niż przykładowo ich rówieśnicy uczący się w szkole z polskim językiem nauczania w Pradze ${ }^{8}$.

8 E. Ogrodzka-Mazur: Tożsamość kulturowa dzieci, rodziców i nauczycieli - mię- 
Po drugie - bardzo ważnym wyznacznikiem kształtowania poczucia tożsamości kulturowej i tym samym świadomości aksjologicznej młodszych uczniów jest podejmowana wobec nich działalność wychowawcza przez szkołę z polskim językiem nauczania. Jak wskazują rezultaty wielu badań prowadzonych w tym zakresie, szkoła na Pograniczu, tak jak większość placówek oświatowych - wbrew deklarowanym celom - pełni w dalszym ciągu funkcje reprodukcji kulturowej i społecznej. Zdaniem Z. Kwiecińskiego młodzież po przejściu przez cykl kształcenia powszechnego jest pod względem poziomu i charakteru kompetencji poznawczych oraz orientacji społecznej bardziej podobna do swoich rodziców niż do rówieśników o odmiennych warunkach socjalizacji w rodzinie ${ }^{9}$. W badanym środowisku zaolziańskim funkcjonują szkoły, które niewątpliwie stwarzają warunki do wzbogacania tożsamości uczniów w wielu wymiarach - w kierunku tożsamości wielowymiarowej, otwartej, ale istnieją także placówki mniej dynamiczne, w których podejmowane działania sprzyjają zachowaniom adaptacyjnym, zamykaniu uczniów we własnym kręgu kulturowym. Na przykładzie środowiska zaolziańskiego można zatem stwierdzić, że potwierdziła się sformułowana przez Ingleharta

dzy etnicznościa a integracja. W: E. Ogrodzka-Mazur, U. Klajmon-Lech, A. Różańska: Tożsamość kulturowa, religijność i edukacja religijna postrzegana z perspektywy społeczności szkót z polskim językiem nauczania w wybranych krajach europejskich. Cieszyn - Toruń 2014, Wydział Etnologii i Nauk o Edukacji Uniwersytetu Śląskiego, Wydawnictwo Adam Marszałek, s. 53-98.

9 Z. Kwieciński: Dynamika funkcjonowania szkoty. Studium empiryczne z socjologii edukacji. Toruń 1995, UMK, s. 237; tenże: Edukacja wobec opóźnienia kulturowego. „Nauka” 2013, nr 1, s. 19-30. Por. także: A. Gajdzica, E. Ogrodzka-Mazur: Obraz szkoty na Pograniczu w kontekście oczekiwań edukacyjnych uczniów. W: T. Lewowicki, E. Ogrodzka-Mazur, A. Szczurek-Boruta (red.): Poczucie tożsamości i stosunek młodzieży do wybranych kwestii społecznych - studium z pogranicza polsko-czeskiego. Cieszyn - Warszawa - Toruń 2009, Wydział Etnologii i Nauk o Edukacji Uniwersytetu Śląskiego, Wyższa Szkoła Pedagogiczna ZNP w Warszawie, Wydawnictwo Adam Marszałek, s. 169-189; A. Gajdzica, E. Ogrodzka-Mazur: Szkoła na Pograniczu jako środowisko kształtowania aspiracji i planów edukacyjnych młodzieży. W: T. Lewowicki, E. Ogrodzka-Mazur, A. Szczurek-Boruta (red.): Poczucie tożsamości i stosunek młodzieży do wybranych kwestii społecznych - studium z pogranicza polsko-czeskiego. cyt. wyd., s. 190-225; G. Piechaczek-Ogierman: Szkoła na Pograniczu a wyzwania i zadania edukacyjne w środowisku wielokulturowym. W: T. Lewowicki, E. Ogrodzka -Mazur, A. Szczurek-Boruta (red.): Edukacja międzykulturowa - dokonania, problemy, perspektywy. Cieszyn - Warszawa - Toruń 2011, Wydział Etnologii i Nauk o Edukacji Uniwersytetu Śląskiego, Wyższa Szkoła Pedagogiczna ZNP w Warszawie, Wydawnictwo Adam Marszałek, s. 174-194. 
hipoteza socjalizacji, zgodnie z którą podstawowa struktura wartości jednostki odzwierciedla warunki, w jakich została ona wychowana.

\section{Wartości preferowane przez młodzież}

Struktura wartości cenionych przez polską młodzież z klas II gimnazjum i uczniów z klas VIII z Zaolzia (por. wykres 4) różni się nieznacznie od wyborów aksjologicznych dokonanych przez ich młodszych kolegów, szczególnie w zakresie najwyżej cenionych wartości życia i szczęścia rodzinnego oraz znaczenia przypisywanemu wiedzy i wykształceniu.

Młodzież ze szkół z polskim językiem nauczania mieszkająca w czeskiej części pogranicza najwyżej ceni życie rodzinne (85\%), życie wygodne i wolne od problemów (77\%). Nieco mniejsze znaczenie przypisuje wykonywaniu w przyszłości pasjonującej pracy i karierze zawodowej oraz nabywaniu wiedzy i wykształceniu (58\%). Kolejny podsystem w preferencjach aksjologicznych uczniów z klas VIII tworzą wartości związane z życiem pełnych zmian, przygód i atrakcji (54\%) oraz zabezpieczeniem wysokiego standardu życia i dużych zasobów finansowych (49\%). Zdecydowanie mniejszą popularnością cieszą się wśród młodzieży życie wzbudzające szacunek i realizacja wartości moralnych (29\%) oraz popularność, sława i odnoszenie sukcesów. W ostatnim podsystemie znalazły się najniżej preferowane wartości i cele życiowe ukierunkowane na zajmowanie w przyszłości wysokich stanowisk, związane z podejmowaniem decyzji (18\%), aktywność obywatelską i zaangażowanie w sprawy społeczne (16\%) oraz uczestnictwo w kulturze i podejmowanie aktywności artystycznej (13\%).

Wykres 4. Wartości preferowane przez uczniów z klas II gimnazjum z Polski i z klas VIII z Republiki Czeskiej

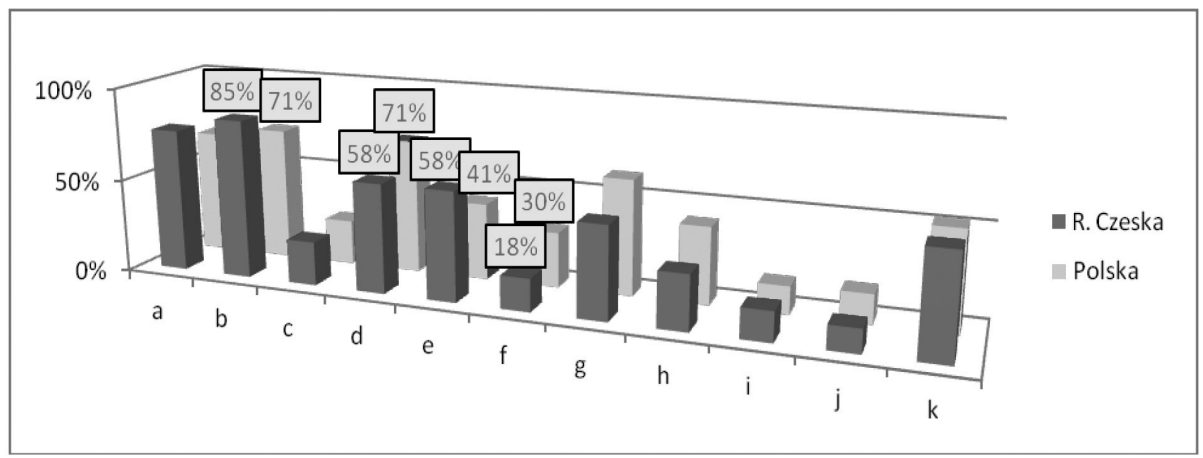

Legenda: a. wygodne życie, wolne od problemów; b. spokojne życie w gronie rodziny 
i przyjaciół; c. popularność, sława, sukcesy; d. pasjonująca praca, kariera zawodowa; e. wiedza, wykształcenie, osiągnięcia naukowe; f. wysokie stanowisko, kierowanie ludźmi, podejmowanie decyzji; g. duży majątek, wysoki standard życia; h. realizacja wartości moralnych, życie wzbudzające szacunek; i. zaangażowanie w sprawy społeczne, aktywność obywatelska; j. udział w kulturze, aktywność artystyczna, twórczość; k. życie pełne zmian, przygód, atrakcji

Źródło: badania własne.

Młodzież gimnazjalna z Polski - w porównaniu z rówieśnikami z Zaolzia - zdecydowanie wyżej ceni (por. wykres 5) wartości związane z:

- z wykonywaniem w przyszłości pasjonującej pracy i realizacją satysfakcjonującej kariery zawodowej $\left(\mathrm{x}^{2}=4,5 ; \mathrm{p}<0,05\right.$; dla $\left.\mathrm{df}=1\right)$,

- zajmowaniem wysokich stanowisk, kierowaniem ludźmi i podejmowaniem decyzji $\left(\chi^{2}=4,8 ; \mathrm{p}<0,05\right.$; dla $\left.\mathrm{df}=1\right)$.

Z kolei uczniowie z klas VIII deklarują jako ważne cele w swoim życiu częściej niż ich rówieśnicy w Polsce:

- spokojne życie w gronie rodziny i przyjaciół $\left(\mathrm{x}^{2}=6,6 ; \mathrm{p}<0,05\right.$; dla $\left.\mathrm{df}=1\right)$,

- zdobycie wiedzy, wykształcenia i osiągnięć naukowych $\left(\chi^{2}=7,3 ; p<0,05\right.$; dla df $=1$ ).

Ogólny obraz wartości preferowanych przez współczesną młodzież z pogranicza polsko-czeskiego w poszczególnych ich podsytemach jest dość jednolity. Niemniej jednak gimnazjaliści z Polski na tym samym poziomie cenią zarówno wartości rodzinne, jak i wykonywanie w przyszłości pasjonującej pracy związanej zarazem ze zdobyciem wysokiej kariery zawodowej. Większą wagę przywiązują także do wartości materialnych, zabezpieczających wysoki standard życia oraz zajmowania wysokich stanowisk kierowniczych. Natomiast uczniowie z klas VIII z Zaolzia deklarują w większym zakresie dążenie do życia rodzinnego, życia wygodnego i wolnego od problemów, jak również wyżej cenią wartość nauki, wiedzy i wykształcenia.

Podejmując próbę interpretacji uzyskanych wyników badań, można stwierdzić, że świat wartości młodzieży jest już w dużym stopniu osadzony w nowej rzeczywistości społeczno-kulturowej, odmiennej od kultury ich rodziców i starszych pokoleń. Badani uczniowie w wieku 16 lat znajdują się w okresie dorastania, w którym młody człowiek uzyskuje dwie istotne zdolności do dalszego rozwoju: zdolność do dawania nowego życia oraz zdolność do samodzielnego kształtowania własnego życia. Rozwój każdej z tych zdolności przypada na różny wiek i rozdziela okres adolescencji na dwie fazy, które w przybliżeniu oddziela właśnie 16. rok życia. Fazę pierwszą określa się 
jako wczesną adolscencję (inaczej wiek dorastania), a drugą - jako późną adolescencję, również nazywaną jako wiek młodzieńczy. Okres adolescencji jest to intensywny czas tworzenia samego siebie i czas, w którym na skutek nieznanych przedtem doznań uczuciowych i nowych sposobów intelektualnego ujmowania zjawisk, kształtuje się osobowość - czas „smakowania” życia ${ }^{10}$. Współcześnie - w zewnętrznej sytuacji określanej przez Zygmunta Baumana "płynną nowoczesnością"11 - młodzież ma przed sobą również bardzo trudne zadanie, związane z potrzebą określenia swojego miejsca w świecie, cechującego się niestałością oraz szeroko rozumianym pluralizmem.

Wykres 5. Porównanie wartości preferowanych przez uczniów z klas II gimnazjum z Polski i z klas VIII z Republiki Czeskiej

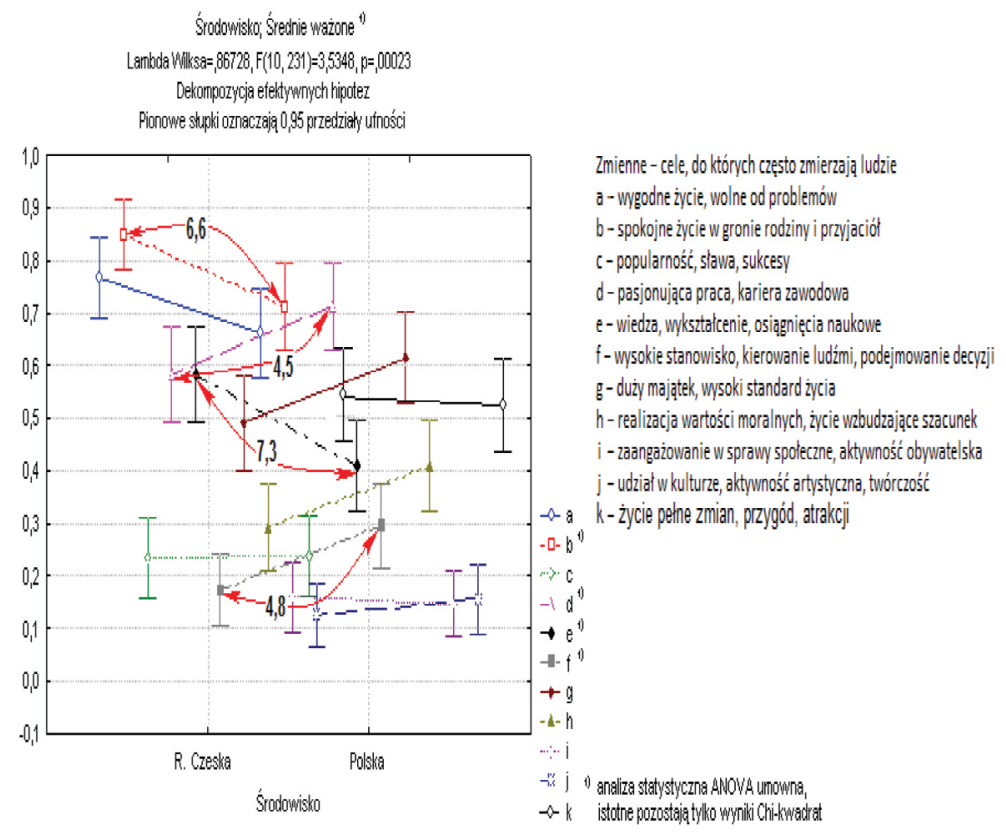

Źródło: badania własne.

10 I. Obuchowska: Adolescencja. W: B. Harwas-Napierała, J. Trempała (red.): Psychologia rozwoju człowieka. T. 2. Charakterystyka okresów życia człowieka. Warszawa 2000, PWN, s. 166-167.

11 Z. Bauman: Ptynna nowoczesność. Kraków 2007, Wydawnictwo Literackie. Tenże: Zindywidualizowane społeczeństwo. Gdańsk 2008, GWP. 
Orientacje aksjologiczne polskich gimnazjalistów skierowane są przede wszystkim na realizację wartości rodzinnych, materialnych oraz indywidualno-prywatnych (autotelicznych), umożliwiających wygodne życie skupione wyłącznie na własnej osobie. Wartości społeczne i kulturowe, będące istotnymi wyznacznikami i regulatorami zachowań, mają zdecydowanie mniejsze znaczenie dla całej badanej grupy - przejawia się zatem wyraźna tendencja nastawienia młodzieży na realizację wybranych, prywatnych wartości w kierunku znalezienia dla siebie sensu życia i własnej tożsamości. Uczniowie, wchodzący w okres dorosłości, aprobują i przejawiają także w swych codziennych zachowaniach afirmowanie wartości przyjemnościowych. Zapewne jest to skutkiem zachodzących przemian społeczno-kulturowych i związanych z nimi procesów: integracją europejską, globalizacją, łatwością dostępu do różnego rodzaju dóbr, gospodarką wolnorynkową, jak również samej zmiany stylu wychowania dzieci przez rodziców. Liberalizacja wychowania rodzinnego rozwija się we współczesnych warunkach ustrojowych znacznie szerzej i intensywniej niż w czasach młodości rodziców badanej młodzieży.

Wartości moralne i życie wzbudzające szacunek zajmują zaniżone miejsce w strukturze (zgodnie z obiektywistycznym podejściem do wartości reprezentowanym w fenomenologicznej koncepcji Schelera) wyborów badanych uczniów. Niższą pozycję tej grupy wartości cenionych przez młodzież, w porównaniu do m.in. wyników badań przeprowadzonych przez T. Lewowickiego w latach 80. ubiegłego wieku, Mirosława J. Szymańskiego w latach 1995-1996, Halinę Świdę-Ziembę w latach 1996-1997 czy Evę Klcovanską na początku nowego stulecia ${ }^{12}$, można interpretować jako uświadomienie sobie przez młodych ludzi większego znaczenia wiedzy i wykształcenia w warunkach gospodarki wolnorynkowej oraz faktu, iż jakość uzyskanych kwalifikacji warunkuje ich losy życiowe, przyszły wykonywany zawód, pracę, stanowisko, warunki życia, a także realizację własnych dążeń życiowych.

Kierowanie się wartościami moralnymi może tym samym pozostawać często w sprzeczności z dokonywanymi wyborami w zakresie indywidualnych celów życiowych. Potwierdzają to zarazem wyniki innych badań, wskazujące również na obniżenie lub całkowity brak znaczenia w preferencjach aksjo-

12 Por.: T. Lewowicki: Aspiracje dzieci i młodzieży. Warszawa 1987, PWN, s. 68; M. Szymański: Mtodzież wobec wartości. Próba diagnozy. Warszawa 2000, IBE, s. 41; H. Świda-Ziemba: Obraz świata i bycie w świecie: z badań młodzieży licealnej. Warszawa 2000, UW, s. 161-190; E. Klcovanská: Hodnotová orientácia súcasnej mládeže a jej význam v pedagogickom procese [online] 2004. http://www.uski.sk/frm_2009/ ran/2004/ran-2004-1-02.pdf (11.01.2016). 
logicznych współczesnej młodzieży z pogranicza polsko-czeskiego wartości religijnych, bezpośrednio powiązanych z kierowaniem się w życiu zachowaniem etycznym wobec siebie i innych. A. Różańska, porównując na końcu pierwszej dekady XXI wieku trzy grupy badanych - młodzież polską, młodzież czeską i młodzież ze szkół z polskim językiem nauczania - stwierdziła, że respondenci prezentują zróżnicowany poziom autodeklaracji religijnych. Młodzież czeska najczęściej przyznawała, że religia nie odgrywa w jej życiu żadnej roli (46\%) lub rolę małą (25,3\%), a młodzież ze szkół z polskim językiem nauczania oraz młodzież polska znacznie częściej przypisywały religii bardzo dużą (odpowiednio 23,3\% i 23,5\%), dużą (23,8\% i 34,5\%) bądź średnią rolę $(28,2 \% \text { i } 24 \%)^{13}$.

W odniesieniu do zmieniającej się religijności w warunkach społeczeństwa pluralistycznego J. Mariański rozważa kilka możliwych hipotez, spośród których za najbardziej prawdopodobną, bo adekwatną dla społeczeństwa polskiego, przyjmuje hipotezę wielokierunkowych przemian religijności (hipotezę transformacji $)^{14}$. Znajduje ona odzwierciedlenie w poglądach młodego pokolenia, z którego ponad 46\% osób uważa, że nie potrzebuje żadnych kodeksów etycznych w życiu, a rozstrzygnięcie o tym, co jest dobre, a co złe, powinno pozostać indywidualną sprawą każdego człowieka ${ }^{15}$. Wybory aksjologiczne młodzieży z pogranicza polsko-czeskiego, a szczególnie polskich gimnazjalistów, wyznaczane są $\mathrm{w}$ dużym stopniu procesami utożsamianymi z coraz większą ekspansją kultury „[...] indywidualizmu, konsumeryzmu i instrumentalizmu oraz określonego typu doświadczania siebie przez jednostkę, a mianowicie doświadczania siebie przez »powołanie« do samorealizacji” ${ }^{16}$. Odnosząc uzyskane wyniki badań do sformułowanych przez Ingleharta i przywołanych już w tym opracowaniu hipotez, można stwierdzić, że szczególnie preferencje aksjologiczne deklarowane przez polską młodzież w wieku

13 A. Różańska: Przemiany świadomości religijnej młodzieży. W: T. Lewowicki, E. Ogrodzka-Mazur, A. Szczurek-Boruta (red.): Poczucie tożsamości i stosunek młodzieży do wybranych kwestii społecznych - studium z pogranicza polsko-czeskiego. cyt. wyd., s. 129-148; tejże: Edukacja religijna młodzieży w warunkach pluralizmu religijnego w wybranych krajach Europy Środkowo-Wschodniej (Grupa Wyszehradzka: Polska, Czechy, Stowacja, Wegry) - studium porównawcze. Cieszyn - Toruń 2015, Wydział Etnologii i Nauk o Edukacji Uniwersytetu Śląskiego, Wydawnictwo Adam Marszałek.

14 J. Mariański: Religijność spoteczeństwa polskiego w perspektywie europejskiej. Próba syntezy socjologicznej. Kraków 2004, Zakład Wydawniczy „Nomos”, s. 17-24.

15 http://www.humanizm.free.ngo.pl/relnowe.pdf (27.08.2010).

16 M. Jacyno: Kultura indywidualizmu. Warszawa 2007, PWN, s. 37. 
gimnazjalnym lokują się w wymiarze autorytetu świecko-racjonalnego oraz wymiarze wartości materialistycznych (przeżycia).

Tak istotne zmiany nie zachodzą przy porównaniu preferencji aksjologicznych uczniów z klas VIII ze szkół z polskim językiem nauczania z wyborami ich rówieśników, dokonanymi w 1990 roku (por. wykres 6). Współczesna młodzież zaolziańska, podobnie jak jej rówieśnicy 25 lat temu, najwyżej ceni wartości życia rodzinnego i wygodnego, wolnego od problemów ${ }^{17}$. Na tym samym poziomie ważne znaczenie mają również dla uczniów pasjonująca praca i kariera zawodowa oraz życie pełne zmian, przygód i atrakcji. Dostrzegalna różnica dotyczy wartości materialnych i edukacyjnych - współczesna młodzież z Zaolzia przywiązuje do nich zdecydowanie większą wagę, potwierdzając z jednej strony swoje orientacje materialistyczne, charakterystyczne dla pokolenia zmiany, a z drugiej - w przeciwieństwie do rówieśników z Polski - osiągnięcie wyższego statusu ekonomicznego i społecznego wiąże przede wszystkim z nauką i wykształceniem. W zakresie układu i podsystemów pozostałych wartości zachodzi duże podobieństwo z badaną grupą uczniów z klas VIII sprzed 25 lat.

Wykres 6. Wartości preferowane przez uczniów z klas VIII z Republiki Czeskiej oraz z klas II gimnazjum z Polski w roku 1990 i 2015

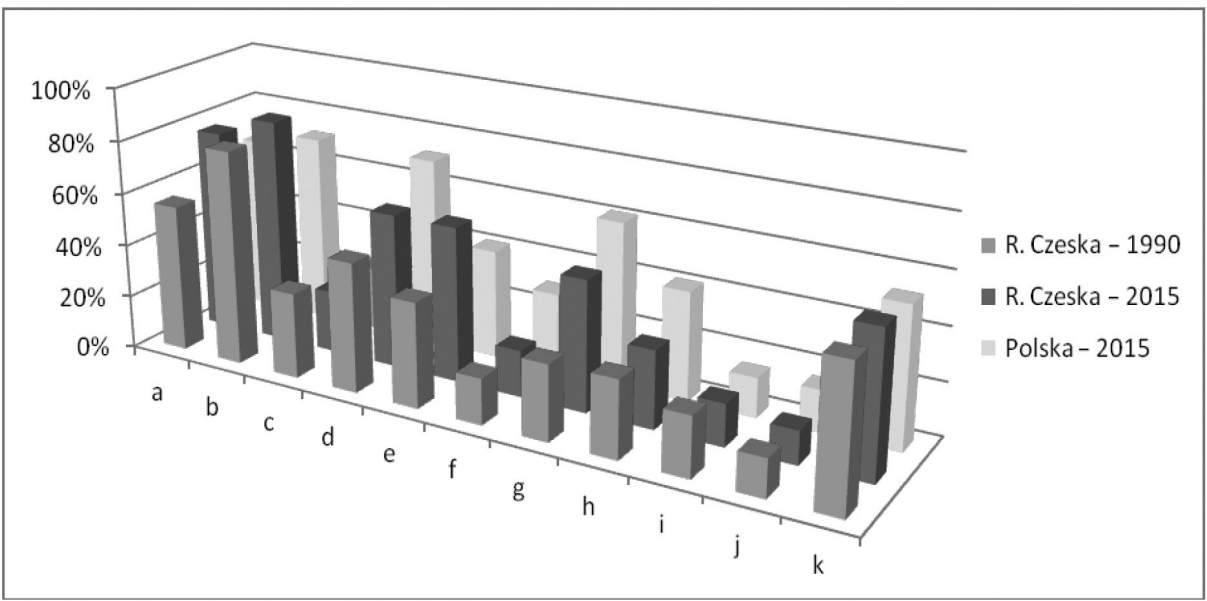

Legenda: a. wygodne życie, wolne od problemów; b. spokojne życie w gronie rodziny

17 E. Ogrodzka-Mazur: Hierarchia wartości (celów życiowych) i siła dążeń (aspiracji) uczniów klas czwartych $i$ ósmych - analiza porównawcza. W: T. Lewowicki (red.): Hierarchia wartości i plany życiowe dzieci z Zaolzia. cyt. wyd., s. 82-93. 
i przyjaciół; c. popularność, sława, sukcesy; d. pasjonująca praca, kariera zawodowa; e. wiedza, wykształcenie, osiągnięcia naukowe; f. wysokie stanowisko, kierowanie ludźmi, podejmowanie decyzji; g. duży majątek, wysoki standard życia; h. realizacja wartości moralnych, życie wzbudzające szacunek; i. zaangażowanie w sprawy społeczne, aktywność obywatelska; j. udział w kulturze, aktywność artystyczna, twórczość; k. życie pełne zmian, przygód, atrakcji

Źródło: badania własne.

Badaną młodzież z czeskiej części pogranicza zarówno w 1990 roku, jak i aktualnie cechuje dostrzegalne podobieństwo w zakresie obrazu preferowanych wartości do struktury wartości cenionych przez jej polskich rówieśników w końcu lat 90. ubiegłego wieku. Podobnie jak w przypadku uczniów z klas IV współczesna młodzież z Zaolzia jest mniej podatna na zachodzące zmiany społeczno-kulturowe, co zapewne warunkuje zarówno bardziej tradycyjne wychowanie w rodzinie i środowisku polskiej mniejszości narodowej, jak i oddziaływanie szkoły z polskim językiem nauczania.

Ważne znaczenie ma również ogólna kondycja ekonomiczna, gospodarcza i społeczno-kulturowa państwa czeskiego, w którym żyje badana młodzież z Zaolzia. W Republice Czeskiej po zmianach ustrojowych wzrosło znaczenie edukacji w osiąganiu indywidualnego sukcesu życiowego ${ }^{18}$. W okresie posttransformacyjnym nie zlikwidowano - jak przykładowo w Polsce - przemysłu hutniczego i surowcowego i tym samym bezrobocie w tym kraju nigdy nie przekroczyło $10 \%$ ogółu społeczeństwa ${ }^{19}$. Charakterystycznym rysem społeczeństwa czeskiego jest również jego sekularyzacja - 63\% młodzieży w tym kraju deklaruje się jako osoby niewierzące. Wyniki badań prowadzonych przez P. Saka i K. Sakovą potwierdzają także, że w społeczeństwie „istnieją względnie trwałe i akceptowane przez ludzi scenariusze życiowe - uzyskanie wykształcenia, kwalifikacji, wykorzystanie tych elementów w pracy, partner, małżeństwo, założenie rodziny" ${ }^{20}$. Zjawiska te warunkują preferencje aksjolo-

18 P. Sak, K. Saková: Mládež na križovatce. Sociologická analýza postavení mládeže ve společnosti a její úlohy v procesach evropeizace a informatizace. Praga 2004, Svoboda Servis, s. 155.

19 K. Heffner: Zmiany ludnościowe i procesy rozwoju w strefie pogranicza Polski z Czechami. W: K. Heffner, W. Drobek (red.): Strefa pogranicza Polska-Czechy. Procesy rozwoju i transformacji. Opole 1996, Państwowy Instytut Naukowy, Instytut Śląski w Opolu, s. 108-130.

20 P. Sak, K. Saková: Mládež na kŕižovatce. Sociologická analýza postavení mládeže ve společnosti a její úlohy v procesach evropeizace a informatizace. cyt. wyd., 
giczne młodzieży zaolziańskiej, która swoje cele i dalsze plany życiowe wiąże z krajem zamieszkania. Aktualnie mniejsza liczba uczniów (16\%) niż w latach 1990-1994 (23,8\%) deklaruje chęć studiowania w przyszłości w Polsce, jak również mniej osób $\left(26 \% ; \chi^{2}=6,3\right.$ dla $\left.\mathrm{p}<0,01\right)$ rozważa taką możliwość (w latach 1990-1994 - 35,2\%). Z kolei więcej młodych Zaolziaków (26\%) nie jest w ogóle zainteresowanych studiami w Polsce i/lub za granicą (w latach 1992-1994 - 17,2\%) i deklarują wybór wyłącznie czeskich uczelni, z którymi wiążą swoje przyszłe plany edukacyjne ${ }^{21}$.

Obraz wartości uczniów z klas VIII bardziej cechuje - w kontekście Ingleharta teorii zmian wartości - świecko-racjonalny autorytet i postmaterializm skierowany na osiągnięcie określonej jakości życia. Może to właśnie młode pokolenie z Zaolzia, jako swoisty „barometr” społeczny, zmierza w kierunku "cichej rewolucji” wartości, będącej pozytywną zmianą, zgodną z transformacją społeczeństwa industrialnego w społeczeństwo usług?

\section{Konkluzje}

W obrazie wartości preferowanych zarówno przez uczniów z Zaolzia, jak i ich rówieśników z Polski można wyodrębnić dominujący zespół wartości życia rodzinnego, wygodnego oraz atrakcyjnego. Wartości rodzinne nadal zajmują wysoką pozycję w wyborach dokonywanych przez badanych, szczególnie z czeskiej części pogranicza, i tym samym wskazują na zachowywaną swoistą ciągłość pokoleniową - rodzina jest najwyżej cenioną wartością, podstawowym środowiskiem wychowawczym oraz miejscem przekazu wartości. Większość dzieci i młodzieży nie jest z kolei zainteresowana zarówno uczestnictwem w kulturze, jak i angażowaniem się w sprawy społeczne oraz podejmowaniem aktywności obywatelskiej w swoich krajach. Bardzo niskie poczucie możliwości oddziaływania na sprawy społeczne przejawiają nie tylko uczniowie z pogranicza polsko-czeskiego, ale jest to zjawisko, które charakteryzuje całe młode pokolenie zarówno w Polsce, jak i w Republice Czeskiej.

s. 159. Por. także: K. Kabacińska: Społeczne konstrukcje sukcesu życiowego młodzieży czeskiej. W: D. Hildebrant-Wypych, K. Kabacińska (red.): Młodzież i sukces życiowy. Studium z pedagogiki porównawczej na przykładzie młodzieży polskiej, czeskiej, niemieckiej i holenderskiej. Kraków 2010, Oficyna Wydawnicza „Impuls”, s. 223-292.

21 E. Ogrodzka-Mazur: Wyznaczniki planów życiowych - drogi edukacyjne - dalsze zamierzenia. W: T. Lewowicki (red.): Kulturowe, społeczne i edukacyjne wyznaczniki dróg życiowych młodzieży z Zaolzia. Katowice 1994, UŚ, s. 108-109. 
Preferowane aktualnie wartości przez uczniów z Zaolzia i ich struktura nieznacznie różnią się od wyborów dokonanych 25 lat temu przez ich rówieśników uczęszczających do szkół z polskim językiem nauczania. Współczesna młodzież większe znaczenie przypisuje jedynie pracy i karierze zawodowej, natomiast jeszcze mniej ceni zajmowanie wysokich stanowisk i kierowanie ludźmi oraz angażowanie się w sprawy społeczne i aktywność obywatelską. Tak zbliżona struktura wartości i funkcjonujące w jej obrębie podsystemy - mimo upływu ćwierci wieku - mogą po pierwsze potwierdzać małą podatność na zmiany społeczności polskiej mieszkającej na Zaolziu, determinowaną bardziej tradycyjnym, rodzinnym wychowaniem, przywiązaniem do przeszłości i zachowywaną swoistą ciągłością pokoleniową. Po drugie - bardzo ważnym wyznacznikiem kształtowania poczucia tożsamości kulturowej i tym samym świadomości aksjologicznej uczniów jest podejmowana wobec nich działalność wychowawcza przez szkołę z polskim językiem nauczania, co potwierdzają również wyniki wielu innych badań prowadzonych w obszarze tego pogranicza.

Realizacja i urzeczywistnianie celów życiowych przez badanych jest różnicowane środowiskiem ich życia i preferowanymi wartościami. Można zauważyć tendencję, zgodnie z którą uczniowie ze szkół z polskim językiem nauczania skupiają przede wszystkim swoją uwagę na zespole celów życia rodzinnego, wygodnego i atrakcyjnego, które potrafią osiągnąć, które będzie im najłatwiej realizować i które już przynajmniej częściowo urzeczywistniają. Ich rówieśnicy z polskiej części pogranicza najczęściej nie utożsamiają celów, które będą starali się realizować w życiu, z tymi - które potrafią osiągnąć. Ponadto - w kontekście uwarunkowań ekonomicznych, społecznych i kulturowych swojego kraju - przejawiają zawyżoną ocenę swoich szans i możliwości w zakresie realizacji wszystkich dążeń życiowych.

Ogólny obraz preferencji aksjologicznych badanych cechuje obniżenie się poziomu całościowego systemu wartości, nasilająca się współcześnie tendencja do ześrodkowania uwagi na życiu dla siebie, wzrost znaczenia wartości indywidualno-prywatnych, w przeciwieństwie do wartości o charakterze społecznym, oraz dążenie do samorealizacji, rozumianej jako postępowanie zgodne z własnymi możliwościami i potrzebami, i zarazem odrzucające wszelkie ideologie, z religijną włącznie. 


\section{Bibliografia}

Bauman Z.: Ptynna nowoczesność. Kraków 2007, Wydawnictwo Literackie. Bauman Z.: Zindywidualizowane społeczeństwo. Gdańsk 2008, GWP. Frankfort-Nachmias Ch., Nachmias D.: Metody badawcze w naukach społecznych. Poznań 2001, Zysk i S-ka.

Gajdzica A., Ogrodzka-Mazur E.: Obraz szkoty na Pograniczu w kontekście oczekiwań edukacyjnych uczniów. W: T. Lewowicki, E. Ogrodzka-Mazur, A. Szczurek-Boruta (red.): Poczucie tożsamości i stosunek młodzieży do wybranych kwestii społecznych - studium z pogranicza polsko-czeskiego. Cieszyn - Warszawa - Toruń 2009, Wydział Etnologii i Nauk o Edukacji Uniwersytetu Śląskiego, Wyższa Szkoła Pedagogiczna ZNP w Warszawie, Wydawnictwo Adam Marszałek.

Gajdzica A., Ogrodzka-Mazur E.: Szkoła na Pograniczu jako środowisko ksztattowania aspiracji i planów edukacyjnych młodzieży. W: T. Lewowicki, E. Ogrodzka-Mazur, A. Szczurek-Boruta (red.): Poczucie tożsamości i stosunek młodzieży do wybranych kwestii społecznych - studium z pogranicza polsko-czeskiego. Cieszyn - Warszawa - Toruń 2009, Wydział Etnologii i Nauk o Edukacji Uniwersytetu Śląskiego, Wyższa Szkoła Pedagogiczna ZNP w Warszawie, Wydawnictwo Adam Marszałek.

Hajduk E. (red.): Metoda panelu: różne aplikacje. Zielona Góra 1993, WSP.

Heffner K.: Zmiany ludnościowe i procesy rozwoju w strefie pogranicza Polski z Czechami. W: K. Heffner, W. Drobek (red.): Strefa pogranicza Polska Czechy. Procesy rozwoju i transformacji. Opole 1996, Państwowy Instytut Naukowy, Instytut Śląski w Opolu.

Inglehart R. F. et al.: World values surveys an European values surveys, 1999-2001. User guide and codebook. Michigan 2004, University of Michigan. Inglehart R. F.: Pojawienie sie postmaterialnych wartości. W: P. Sztompka, M. Kucia (red.): Socjologia. Lektury. Kraków 2007, „Znak”.

Jacyno M.: Kultura indywidualizmu. Warszawa 2007, PWN.

Kabacińska K.: Społeczne konstrukcje sukcesu życiowego młodzieży czeskiej. W: D. Hildebrant-Wypych, K. Kabacińska (red.): Młodzież i sukces życiowy. Studium z pedagogiki porównawczej na przykładzie młodzieży polskiej, czeskiej, niemieckiej i holenderskiej. Kraków 2010, Oficyna Wydawnicza „Impuls”. Klcovanská E.: Hodnotová orientácia súcasnej mládeže a jej význam v pedagogickom procese. [online]. http://www.uski.sk/frm_2009/ran/2004/ran2004-1-02.pdf (11.07.2016). 
Kleszcz M., Łączyk M.: Mtodzież licealna wobec wartości, samotności i pasji. Katowice - Kraków 2012, UŚ, Oficyna Wydawnicza „Impuls”.

Kwieciński Z.: Dynamika funkcjonowania szkoty. Studium empiryczne z socjologii edukacji. Toruń 1995, UMK.

Kwieciński Z.: Edukacja wobec opóźnienia kulturowego. „Nauka” 2013, nr 1. Lewicka M.: „Polacy sq wielkim i dumnym narodem”, czyli nasz portret (wielce) zróżnicowany. W: M. Drogosz (red.): Jak Polacy przegrywają, Jak Polacy wygrywaja. Gdańsk 2005, GWP.

Lewowicki T.: Aspiracje dzieci i młodzieży. Warszawa 1987, PWN.

Lewowicki T., Suchodolska J. (red.): Rodzina - Wychowanie - Wielokulturowość. Cieszyn 2000, UŚ - Filia w Cieszynie, Wyższa Szkoła Pedagogiczna ZNP w Warszawie.

Lewowicki T., Ogrodzka-Mazur E., Minczanowska A., Piechaczek-Ogierman G.: Sfery życia duchowego dzieci i młodzieży - studium z pogranicza polsko-czeskiego. T. 1. Przemiany wartości i aspiracji życiowych. Cieszyn Toruń 2016, Wydział Etnologii i Nauk o Edukacji Uniwersytetu Śląskiego, Wydawnictwo Adam Marszałek.

Mariański J.: Religijność społeczeństwa polskiego w perspektywie europejskiej. Próba syntezy socjologicznej. Kraków 2004, Zakład Wydawniczy „Nomos”.

Obuchowska I.: Adolescencja. W: Harwas-Napierała B, Trempała J. (red.): Psychologia rozwoju człowieka. T. 2. Charakterystyka okresów życia człowieka. Warszawa 2000, PWN.

Ogrodzka-Mazur E.: Systemy wartości, aspiracje i plany życiowe uczniów klas czwartych z Czeskiego Cieszyna i Orłowej. W: T. Lewowicki (red.): Hierarchia wartości i plany życiowe dzieci z Zaolzia. Cieszyn 1992, UŚ - Filia w Cieszynie.

Ogrodzka-Mazur E.: Hierarchia wartości (celów życiowych) i siła dążeń (aspiracji) uczniów klas czwartych i ósmych - analiza porównawcza. W: T. Lewowicki (red.): Hierarchia wartości i plany życiowe dzieci z Zaolzia. Cieszyn 1992, UŚ - Filia w Cieszynie.

Ogrodzka-Mazur E.: Wyznaczniki planów życiowych - drogi edukacyjne dalsze zamierzenia. W: T. Lewowicki (red.): Kulturowe, społeczne i edukacyjne wyznaczniki dróg życiowych młodzieży z Zaolzia. Katowice 1994, UŚ. Ogrodzka-Mazur E.: Rodzina i dziecko w otoczeniu wielokulturowym. Relacje międzypokoleniowe i ich rola w przekazie wartości. W: T. Lewowicki, E. Ogrodzka-Mazur, A. Szczurek-Boruta (red.): Edukacja międzykulturowa - dokonania, problemy, perspektywy. Cieszyn - Warszawa - Toruń 2011, Wydział Etnologii i Nauk o Edukacji Uniwersytetu Śląskiego, 
Wyższa Szkoła Pedagogiczna ZNP w Warszawie, Wydawnictwo Adam Marszałek.

Ogrodzka-Mazur E.: Tożsamość kulturowa dzieci, rodziców i nauczycieli między etnicznościa a integracją. W: E. Ogrodzka-Mazur, U. Klajmon-Lech, A. Różańska: Tożsamość kulturowa, religijność i edukacja religijna postrzegana z perspektywy spoteczności szkót z polskim językiem nauczania w wybranych krajach europejskich. Cieszyn - Torun 2014, Wydział Etnologii i Nauk o Edukacji Uniwersytetu Śląskiego, Wydawnictwo Adam Marszałek.

Piechaczek-Ogierman G.: Szkoła na Pograniczu a wyzwania i zadania edukacyjne w środowisku wielokulturowym. W: T. Lewowicki, E. Ogrodzka -Mazur, A. Szczurek-Boruta (red.): Edukacja międzykulturowa - dokonania, problemy, perspektywy. Cieszyn - Warszawa - Torun 2011, Wydział Etnologii i Nauk o Edukacji Uniwersytetu Śląskiego, Wyższa Szkoła Pedagogiczna ZNP w Warszawie, Wydawnictwo Adam Marszałek.

Pilch T., Bauman T.: Zasady badań pedagogicznych. Podejście ilościowe i jakościowe. Warszawa 2001, Wydawnictwo Akademickie „Żak”.

Różańska A.: Przemiany świadomości religijnej młodzieży. W: T. Lewowicki, E. Ogrodzka-Mazur, A. Szczurek-Boruta (red.): Poczucie tożsamości i stosunek młodzieży do wybranych kwestii społecznych - studium z pogranicza polsko-czeskiego. Cieszyn - Warszawa - Toruń 2009, Wydział Etnologii i Nauk o Edukacji Uniwersytetu Śląskiego, Wyższa Szkoła Pedagogiczna ZNP w Warszawie, Wydawnictwo Adam Marszałek.

Różańska A.: Edukacja religijna młodzieży w warunkach pluralizmu religijnego w wybranych krajach Europy Środkowo-Wschodniej (Grupa Wyszehradzka: Polska, Czechy, Słowacja, Wegry) - studium porównawcze. Cieszyn - Toruń 2015, Wydział Etnologii i Nauk o Edukacji Uniwersytetu Śląskiego, Wydawnictwo Adam Marszałek.

Sak P., Saková K.: Mládež na kŕižovatce. Sociologická analýza postavení mládeže ve společnosti a její úlohy v procesach evropeizace a informatizace. Praga 2004, Svoboda Servis.

Świda-Ziemba H.: Obraz świata i bycie w świecie: $z$ badań młodzieży licealnej. Warszawa 2000, UW.

Szymański M.: Mtodzież wobec wartości. Próba diagnozy. Warszawa 2000, IBE.

Zdziech P.: Ronalda Ingleharta teoria rozwoju ludzkiego. Kraków 2010, Zakład Wydawniczy „Nomos”. 


\section{Axiological preferences of children and youth from the Polish-Czech borderline. From material to post-material values}

\section{Summary}

What has been described in this study are the transformations of the values appreciated by children and youth in the Polish-Czech borderland. This is done in reference to Ronald F. Inglehart's hypotheses of scarcity and socialization. They assume that: firstly, the individual's priority values reflect his/her socio-economic environment and the relatively scarce objects in this environment are attributed a subjectively bigger value, and secondly - that the individual's basic structure of values reflects the conditions in which $\mathrm{s} /$ he has been brought up.

The studies, conducted in 1990-1991 and 2014-2015 with the use of longitudinal comparisons based on the time criterion, allowed for recognizing the determinants of the young generation's axiological preferences, for presenting the relative dynamics of the change as well as for capturing the mechanisms which determine this change.

Key words: values, axiological preferences, cultural borderland, multi- and intercultural education 